\title{
The orchid-bee faunas (Hymenoptera: Apidae) of two Atlantic Forest remnants in southern Bahia, eastern Brazil
}

\author{
Nemésio, A.* \\ Instituto de Biologia, Universidade Federal de Uberlândia - UFU, Rua Ceará, s/n, Campus Umuarama, \\ CEP 38400-902, Uberlândia, MG, Brazil \\ *e-mail: andre.nemesio@gmail.com
}

Received March 2, 2012 - Accepted May 2, 2012 - Distributed May 31, 2013

(With 2 figures)

\begin{abstract}
The orchid-bee faunas of the 'Parque Nacional do Pau Brasil' (8,500 ha) and 'RPPN Estação Veracel' (6,000 ha), two Atlantic Forest remnants in the southern state of Bahia, northeastern Brazil, were surveyed. Seventeen chemical compounds were used as scent baits to attract orchid-bee males. Seven hundred and twelve males belonging to 20 species were actively collected with insect nets during 80 hours in February and April, 2009. Euglossa marianae Nemésio, 2011, the most sensitive orchid-bee species of the Atlantic Forest, was recorded at both preserves, though in low abundance. 'RPPN Estação Veracel' is the smallest forest patch where Euglossa marianae has ever been recorded.
\end{abstract}

Keywords: Atlantic Forest, conservation, Euglossina, euglossine bees, Hexapoda.

\section{As faunas de abelhas-das-orquídeas (Hymenoptera: Apidae) de dois remanescentes de Mata Atlântica do sul da Bahia, leste do Brasil}

\begin{abstract}
Resumo
As faunas de abelhas-das-orquídeas do Parque Nacional do Pau-Brasil (8,500 ha) e da RPPN Estação Veracel (6,000 ha), dois remanescentes de Mata Atlântica no sul da Bahia, Nordeste do Brasil, foram amostradas. Dezessete iscas atrativas a machos de abelhas-das-orquídeas foram utilizadas. Setecentos e doze machos pertencentes a 20 espécies foram coletados com o uso de redes entomológicas durante 80 horas, em fevereiro e abril de 2009. Euglossa marianae Nemésio, 2011, a espécie de abelha euglossina mais dependente de ambientes florestais, foi registrada nas duas áreas, embora pouco abundante. A RPPN Estação Veracel é a menor área onde essa espécie já foi coletada.
\end{abstract}

Palavras-chave: Mata Atlântica, conservação, Euglossina, abelhas euglossinas, Hexapoda.

\section{Introduction}

The Brazilian Atlantic Rain Forest was the last of the largest Neotropical biomes to have its orchid-bee fauna (Hymenoptera: Apidae: Euglossina) sampled (Nemésio and Silveira, 2007b; Nemésio, 2009). The region of the southern state of Bahia and northern state of Espírito Santo, known as 'Hileia Baiana', holds one of the most diverse and rich biotas in the planet (Myers, 1988; Mittermeier et al., 1999; Galindo-Leal and Câmara, 2003; Laurance, 2009), with high levels of endemism for many taxonomic groups (e.g., Dean, 1995; Pacheco et al., 1996; Thomas et al., 1997, 1998; Sambuichi et al., 2008). Nonetheless, except for two unpublished studies carried out in the region (BonillaGómez, 1999; Melo, 2005), the orchid-bee fauna of 'Hileia Baiana' remained virtually unknown until now. Recent samplings in this area have shown an astonishingly high richness (Moure, 1996; Neves and Viana, 2003; Nemésio, 2011a, b, c, d, e, 2012, 2013) when compared to other areas in the Atlantic Forest (e.g., Rebêlo and Garófalo, 1991, 1997; Bezerra and Martins, 2001; Santos and Sofia, 2002;
Milet-Pinheiro and Schlindwein, 2005; Alvarenga et al., 2007; Aguiar and Gaglianone, 2008, 2011; Silveira et al., 2011; Mattozo et al., 2011).

The 'Hileia Baiana', however, experienced strong deforestation in the last 40 years, when it is estimated that billions of trees were cut off (Fundação SOS Mata Atlântica, 1993), resulting in a highly fragmented landscape, with only a few larger forest patches left, usually not exceeding 25,000 ha (Ribeiro et al., 2009). Since orchid bees are forest insects and many of its species are highly dependent on well-preserved forest areas (Roubik and Hanson, 2004), species endemic in this region are more prone to population declines and even to extinction. Considering that new species have been recently described from the area (Moure, 1996; Nemésio, 2011b, c, d, 2012), further samplings in the region are still needed to a better knowledge of the actual orchid-bee richness at this part of the Atlantic Forest. 
In this study one area not previously sampled in southern Bahia, the 'Parque Nacional do Pau Brasil', a 8,500-ha national park in the municipality of Porto Seguro, had its orchid-bee fauna surveyed for the first time. Also, the 'Reserva Particular do Patrimônio Natural (RPPN) Estação Veracel', a 6,000-ha private preserve located in the neighbourhood of 'Parque Nacional do Pau Brasil', previously sampled by Melo (2005), was also sampled again for comparison.

\section{Material and Methods}

\subsection{Study sites}

This study was conducted at the 'Parque Nacional do Pau Brasil' (PNPB), a 8,500-ha preserve situated in the municipality of Porto Seguro, in the state of Bahia, northeastern Brazil , and the 'RPPN Estação Veracel' (REV), a 6,000-ha preserve situated in the municipality of Santa Cruz Cabrália, ca. $40 \mathrm{~km}$ northeastern from PNPB
(Figure 1), in February (REV) and April (PNPB), 2009, when orchid bees are most actively foraging in the region (e.g., Nemésio, 2011a, b). The vegetation in the region is essentially dense Atlantic Rain Forest [Central Lowland Forest according to vegetational physiognomic classification by Thomas and Carvalho (2003)]. Most of both preserves consists of secondary forests in various successional stages, since pastures, Eucalyptus, other crops and mainly cocoa plantations surround the area and occurred in some parts of the preserves. Pristine forest is still found in a small area at REV. More areas of pristine forest can be found at PNPB, which forest is better developed than at REV. Precipitation in the area is $c a .1,300 \mathrm{~mm} /$ year (Thomas and Carvalho, 2003).

\subsection{Sampling}

Twenty hours of active sampling with insect nets were performed in each of two selected sites in each preserve, totalling 80 hours, following the methodology proposed by Nemésio (2010a, b, 2011a, b): PNPB site-1 (16³1'
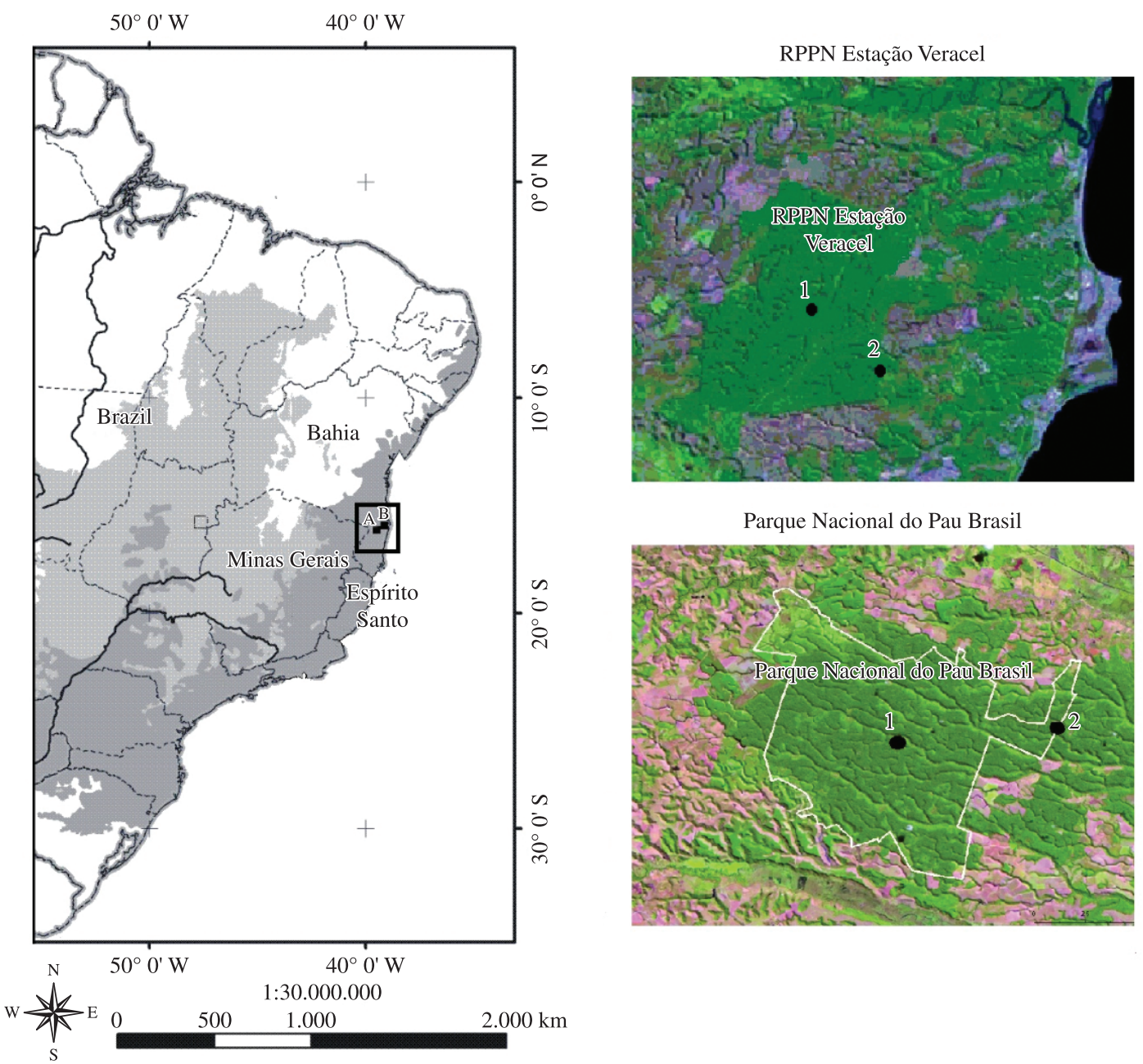

Figure 1. Map showing the exact locations of 'Parque Nacional do Pau Brasil' and 'RPPN Estação Veracel' in southern Bahia, eastern Brazil, and the exact locations of the sampling sites (black circles) within each area. 
11 " S, 39॰ 17' 09" W, ca. $90 \mathrm{~m}$ above sea level) was sampled on the $15^{\text {th }}$ (from 11:00 AM to $2: 00 \mathrm{PM}$ ), $16^{\text {th }}$ (from 9:00 AM to 3:00 PM), and on the $18^{\text {th }}$ (from 9:00 AM to 2:00 PM) of April, 2009; PNPB site-2 (16 $28^{\circ}$ '56" S, 39 13 ' 24" W, ca. $90 \mathrm{~m}$ above sea level) was sampled from the $19^{\text {th }}, 20^{\text {th }}$ and $21^{\text {st }}$ of April, 2009, from 8:00 AM to 3:00 PM (except on the $21^{\text {st }}$ of April, from 9:00 AM to 3:00 PM); REV site-1 (16 20 ' $07^{\prime}$ ' S, 39 $07^{\circ}$ ' 37' W, ca. $90 \mathrm{~m}$ above sea level) was sampled from the $4^{\text {th }}$ to the $6^{\text {th }}$ of February, 2009, from 9:00 AM to 4:00 PM (except on the $6^{\text {th }}$ of February, from 9:00 AM to 3:00 PM); REV site-2 (16 22' 09' ' S, 39॰06' 43" W, ca. $110 \mathrm{~m}$ above sea level) was sampled from the $7^{\text {th }}$ to the $9^{\text {th }}$ of February, 2009, from 9:00 AM to 4:00 PM (except on the $7^{\text {th }}$ of February, from 9:00 AM to 3:00 PM). PNPB site 1 and REV site 1 were situated in the interior of the forest, in pristine areas, whereas PNPB site 2 and REV site 2 were located close to the edge, to better sample the different physiognomies at the preserves. At each site, 17 scent baits were placed ca. $2.0 \mathrm{~m}$ apart from each other at about $1.5 \mathrm{~m}$ above the ground. These baits were made of cotton wadding soaked with one of the following substances, known or believed to be attractive to orchid bees: benzyl acetate, benzyl alcohol, $r$-carvone, 1,8-cineole, $p$-cresol acetate, dimethoxybenzene, eugenol, $\beta$-ionone, methyl benzoate, methyl trans-cinnamate, heneicosane, methyl salicylate, skatole, tricosane, $p$-tolyl acetate, vanillin, and a mixture (1:1) of methyl trans-cinnamate and $p$-tolyl acetate. Baits with cineole, the most volatile compound, were recharged every hour. Bees arriving on the baits during the sampling period were collected with insect nets and killed with ethyl acetate. They were labelled as belonging to the project "Euglossina da Hileia Baiana" and were deposited at the Entomological Collection of the Universidade Federal de Minas Gerais (UFMG), where they were numbered from 19282-55494 to 19444-55928 (specimens collected at REV) and from 19604-56564 to 19730-56584 (specimens collected at PNPB).

\subsection{Data analysis}

Diversity was estimated with the Shannon-Wiener diversity index $\left(H^{\prime}\right)$, as $H^{\prime}=-\sum p_{i} \ln \left(p_{i}\right)$, where $p_{i}$ is the proportion of total number of species made up of the ith species (Pielou, 1975). Evenness (E) was estimated with the formula $E=H^{\prime} / l n(S)$, where $S$ is the species richness. The similarity in faunistic composition among all sites was estimated by the percent similarity index of Renkonen, recommended by Wolda (1981) for small samples. Based on those similarities, the areas were grouped using UPGMA (Sneath and Sokal, 1973).

\subsection{Taxonomy}

Taxonomy follows Nemésio and Rasmussen (2011) with the additions provided by Hinojosa-Díaz et al. (2012), Nemésio (2012), and Nemésio and Engel (2012).

\section{Results}

Seven hundred and twelve orchid-bee males belonging to 20 species in three genera were collected in the present study, two hundred and seventy-two specimens (in 18 species) at PNPB and four hundred and forty individuals (in 17 species) at REV (Table 1). Euglossa mixta Friese, 1899 (23\% of all collected bees) and Eg. carolina Nemésio, 2009 (20\%) were the most common species at PNPB and Eg. imperialis Cockerell, 1922 (22\%) and Eg. carolina (17.5\%) were the most common species at REV (Table 1). The only species represented by a singleton was Eg. pleosticta Dressler, 1982. The same sampling effort was carried out in all four sites, allowing a direct comparison. Abundance was higher at REV (ca. eleven specimens/hour) than at PNPB (ca. seven specimens/hour). Diversity and evenness were high and very similar among all sites. $\left(\mathrm{H}^{\prime}=2.20\right.$ to $2.25 ; \mathrm{E}=0.79$ to 0.81 ) (Table 1 ). The ordination of the sites according to their faunas (Figure 2) showed a relatively low overall similarity among sites, but each site showed roughly the same similarity when compared to each other (ranging from 54\% to 67\%). Both sites at REV grouped together, with ca. $67 \%$ similarity, and both sites at PNPB also grouped together, with some $63 \%$ similarity, and then both sets grouped with ca. $60 \%$ similarity (Figure 2). REV-2 and PNPB-2, both sites situated at the forest edge, showed ca. $64 \%$ similarity.

\section{Discussion}

\subsection{Ecology and faunistics}

The efficiency of the sampling methodology used here was previously discussed in depth (Nemésio, 2010b, 2011a, b; Nemésio et al., 2012). The relatively low abundance found in the present study (seven to eleven specimens/ hour), compared to other studies carried out at the same region (Nemésio, 2011a, b, 2013), should be understood as natural of the sampled areas. Another large preserve, the 'Reserva Biológica de Una', also in southern Bahia, was sampled just a few days before the samplings at the 'RPPN Estação Veracel', with a higher abundance (14 specimens/ hour) (Nemésio, 2013). Similarly, samplings at the nearby 'Parque Nacional do Monte Pascoal' and adjacent forest patches some days before and after samplings at 'PN Pau Brasil' revealed a higher abundance (unpub. data).

Diversity, evenness and richness were very similar among all sampled sites. The overall similarity among sites (Figure 2), however, was not particularly high. In other studies in the Atlantic Forest, sites situated in different forest patches, even with urban matrix among them (Nemésio and Silveira, 2007a, 2010), presented similarities higher than those presented here. Also, sites sampled at the same forest patch in other studies (e.g., Tonhasca Junior et al., 2002; Nemésio and Silveira, 2006) showed higher similarities. On the other hand, the overall similarities reported here are similar to those found among sites at the nearby 'Reserva Biológica de Una' (Nemésio, 2013). This suggests that either the sampling effort, in 
Table 1. Diversity, evenness, species richness and number of specimens of each orchid-bee species collected at sites 1 (forest) and 2 (edge) at both 'Parque Nacional do Pau Brasil' (PNPB) and 'RPPN Estação Veracel' (REV) in southern part of the state of Bahia, northeastern Brazil, after 20 hours of sampling at each site.

\begin{tabular}{lccccc}
\hline \multicolumn{1}{c}{ Species } & PNPB1 & PNPB2 & REV1 & REV2 & Total \\
\hline Euglossa adiastola Hinojosa-Díaz, Nemésio \& Engel, 2012 & 02 & 01 & 04 & 02 & 09 \\
Euglossa avicula Dressler, 1982 & 06 & 00 & 08 & 11 & 25 \\
Euglossa carolina Nemésio, 2009 & 11 & 44 & 22 & 55 & 132 \\
Euglossa clausi Nemésio \& Engel, 2012 & 02 & 03 & 04 & 05 & 14 \\
Euglossa cognata Moure, 1970 & 06 & 03 & 00 & 00 & 09 \\
Euglossa despecta Moure, 1968 & 01 & 03 & 01 & 01 & 06 \\
Euglossa ignita Smith, 1874 & 01 & 05 & 25 & 41 & 72 \\
Euglossa imperialis Cockerell, 1922 & 09 & 20 & 65 & 33 & 127 \\
Euglossa marianae Nemésio, 2011b & 13 & 10 & 02 & 00 & 25 \\
Euglossa milenae Bembé, 2007 & 00 & 02 & 00 & 00 & 02 \\
Euglossa mixta Friese, 1899 & 44 & 19 & 16 & 06 & 85 \\
Euglossa pleosticta Dressler, 1982 & 00 & 00 & 00 & 01 & 01 \\
Euglossa roubiki Nemésio, 2009 & 18 & 10 & 35 & 18 & 81 \\
Euglossa pepei Nemésio \& Engel, 2012 & 02 & 02 & 00 & 00 & 04 \\
Eulaema atleticana Nemésio, 2009 & 03 & 03 & 09 & 16 & 31 \\
Eulaema marcii Nemésio, 2009 & 02 & 01 & 02 & 02 & 07 \\
Eulaema nigrita Lepeletier, 1841 & 06 & 09 & 06 & 08 & 29 \\
Eulaema niveofasciata (Friese, 1899) & 04 & 03 & 11 & 17 & 35 \\
Exaerete frontalis (Guérin-Méneville, 1844) & 00 & 00 & 01 & 04 & 05 \\
Exaerete smaragdina (Guérin-Méneville, 1844) & 02 & 02 & 05 & 04 & 13 \\
Total & $\mathbf{1 3 2}$ & $\mathbf{1 4 0}$ & $\mathbf{2 1 6}$ & $\mathbf{2 2 4}$ & $\mathbf{7 1 2}$ \\
Species richness (S) & 17 & 17 & 16 & 16 & 20 \\
Shannon-Wiener diversity index (H') & 2.26 & 2.25 & 2.20 & 2.25 & 2.44 \\
Evenness (E) & 0.80 & 0.79 & 0.80 & 0.81 & 0.81 \\
\hline
\end{tabular}

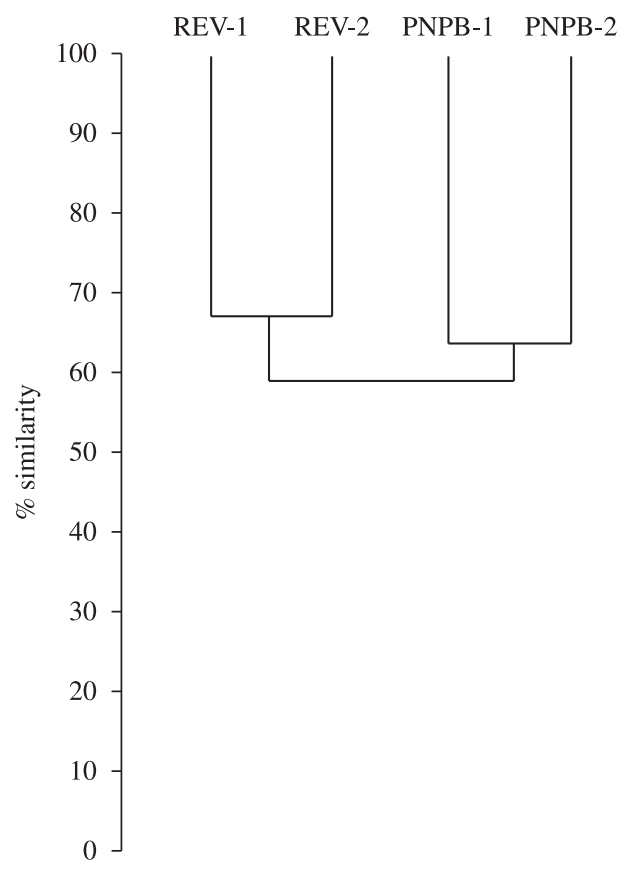

Figure 2. Clustering of the four sites at 'Parque Nacional do Pau Brasil' (PNPB) and 'RPPN Estação Veracel' (REV), eastern Brazil, according to the similarity of their orchid bee faunas. spite of resulting in a high number of collected bees, is still not effective enough to thoroughly sample each site or that within-habitat heterogeneity (see Armbruster, 1993) should be considered when sampling areas with higher diversity - although Melo (2005), when sampling many sites at REV (see discussion below) found results very similar to those presented here.

A previous study had been carried out at 'RPPN Estação Veracel' (Melo, 2005), but for that unpublished Master's Thesis work, a different methodology was used: bait traps were used to attract and collect the bees, instead of active collecting with hand nets (present study) and, thus, comparisons should be made carefully. Nemésio and Morato (2006) have shown that bait traps introduce a bias, since the larger bees of the genus Eulaema tend to proportionally increase their numbers in such samplings, because the smaller Euglossa escape more easily. Mattozo et al. (2011) later confirmed Nemésio and Morato's (2006) results. Melo (2005) collected the same four species of Eulaema recorded in the present study (for differences in species nomenclature used in both studies, see Nemésio, 2009, 2011a) and Eulaema species represented 13.5\% of the orchid-bee community, whereas they represented 9.7\% in the present study (only REV sites considered, for comparison). 
Four of the five most common species in Melo's (2005) study were also the most common in the present study: Eg. imperialis represented $22 \%$ of the specimens in Melo's study (22.3\% in the present study); Eg. ignita represented $21.8 \%$ in 2005 (15\% in the present study); Eg. carolina, then considered as Eg. cordata (Linnaeus, 1758), represented $17.1 \%$ in 2005 (17.5\% in the present study), and Eg. mixta Friese, 1899 declined from $11.4 \%$ to $5 \%$ in the present study. Melo (2005) collected 22 species at REV (17 species were collected in the present study), the difference was due to two species of Eufriesea Cockerell, 1908 (no Eufriesea species was collected in the present study) and four species of Euglossa collected in low abundances by Melo (2005) - counterbalanced by the collection of Eg. marianae in the present study, a species not collected by Melo (2005).

The presence of Eg. marianae at REV is remarkable, because it is the smallest forest patch where this species was ever found, together with 'Estação Ecológica (ESEC) de Murici', in Alagoas (Nemésio, 2010b). As happened at ESEC Murici, the population of this species seems to be very tiny at REV and the only two recorded males were collected at the site in the interior of the forest, as usually preferred by this species (see Tonhasca Junior et al., 2002; Nemésio and Silveira, 2006).

The nine specimens of Eg. cognata Moure, 1970 collected at PNPB represent the northernmost record of this species in the Atlantic Forest. Previous studies at the 'Parque Estadual da Serra do Conduru' (Nemésio, 2011a) and at the 'Reserva Biológica de Una' (Nemésio, 2013), two areas some $100 \mathrm{~km}$ north of the areas sampled in the present study, failed to sample this species. Euglossa cognata seems to be a species dependent on well-preserved forest areas (see Nemésio and Silveira, 2006) and its absence from the neighbor REV [not collected by Melo (2005), either] supports this interpretation.

After comparing Melo's (2005) study and the sampling at 'Parque Estadual da Serra do Conduru', Nemésio (2011b) concluded that twenty-six orchid-bee species occurred in the region. Three additional species were recently recorded at 'REBIO Una' (Nemésio, 2013), raising the number of known species in this area to 29.

\subsection{Final remarks}

Similar to many other "protected" natural areas in northeastern Brazil, the situation faced by both preserves is problematic (few personnel to patrol the area; presence of hunters and wood dealers; legal problems with former owners of the land; invasion by "alleged" Indians who claim the area). As a private preserve belonging to a large company dealing with cellulose, REV maintains a professional team of park guards who patrol the area. Nevertheless, this area is more close to urban areas than PNPB, which makes it easier the access of hunters and wood dealers. On the other hand, PNPB is a public national park, which is virtually abandoned by the government, as happens to almost all Brazilian forested preserves belonging to the Brazilian government. Only four men were responsible for patrolling this 8,500-ha national park when I visited the area, an obviously insufficient number to adequately patrol such a large area. The presence of apparently sensitive orchid-bee species, such as Eg. marianae (see Tonhasca Junior et al., 2002; Nemésio and Silveira, 2006; Nemésio, 2010b, 2011b), Eg. roubiki and the recently described Euglossa pepei Nemésio and Engel, 2012, suggests that these areas, especially PNPB, still hold an important habitat for most, if not all, local orchid bees.

Acknowledgements - The Brazilian government, through the environmental departments IBAMA and ICMBio, provided the collecting permit (\#18798-1). I express my gratitude to Raquel Mendes Miguel and Luiz Fernando Brutto, administrators of the 'Parque Nacional do Pau Brasil' and Olândia F. Lopes and Lígia Gallozzi M. Andrade, from 'RPPN Estação Veracel', who were very helpful during my field research. Two anonymous referees made valuable comments on a first draft of this manuscript.

\section{References}

AGUIAR, WM. and GAGLIANONE, MC., 2008. Comunidade de abelhas Euglossina (Hymenoptera: Apidae) em remanescentes de mata estacional semidecidual sobre tabuleiro no estado do Rio de Janeiro. Neotropical Entomology, vol. 37, p. 118-125. PMid:18506288. http://dx.doi.org/10.1590/S1519-566X2008000200002

-, 2011. Euglossine bees (Hymenoptera Apidae Euglossina) on an inselberg in the Atlantic Forest domain of southeastern Brazil. Tropical Zoology, vol. 24, p. 107-125.

ALVARENGA, PEF., FREITAS, RF. and AUGUSTO, SC., 2007. Diversidade de Euglossini (Hymenoptera: Apidae) em áreas de Cerrado do Triângulo Mineiro, MG. Bioscience Journal, vol. 23 Suppl. 1, p. 30-37.

ARMBRUSTER, WS., 1993. Within-habitat heterogeneity in baiting samples of male euglossine bees: possible causes and implications. Biotropica, vol. 25, p. 122-128. http://dx.doi. org/10.2307/2388986

BEZERRA, CP. and MARTINS, CF., 2001. Diversidade de Euglossinae (Hymenoptera, Apidae) em dois fragmentos de Mata Atlântica localizados na região urbana de João Pessoa, Paraíba, Brasil. Revista Brasileira de Zoologia, vol. 18, p. 823-835. http:// dx.doi.org/10.1590/S0101-81752001000300018

BONILLA-GÓMEZ, MA., 1999. Caracterização da Estrutura Espaço-temporal da Comunidade de Abelhas Euglossinas (Hymenoptera, Apidae) na Hiléia Bahiana. Unpublished Ph. D. Dissertation. Universidade Estadual de Campinas, Campinas, Brazil. 153 p.

DEAN, W., 1995. With Broadax and Firebrand - The Destruction of the Brasilian Atlantic Forest. Berkeley: University of California Press.

Fundação SOS Mata Atlântica., 1993. Dossiê Mata Atlântica. São Paulo: Fundação SOS Mata Atlântica.

GALINDO-LEAL, C. and CÂMARA, IG., 2003. Atlantic Forest hostpot status: an overview. In GALINDO-LEAL, C. and CÂMARA, I.G. (Eds.). The Atlantic Forest of South America - biodiversity status, threats, and outlook. Washington: Island Press. p. 3-11.

HINOJOSA-DÍAZ, IA., NEMÉSIO, A. and ENGEL, MS., 2012. Two new species of Eugossa from South America, with notes on their taxonomic affinities (Hymenoptera, Apidae). ZooKeys, vol. 
221, p. 63-79. PMid:23129981 PMCid:3487635. http://dx.doi. org/10.3897/zookeys.221.3659

LAURANCE, WF., 2009. Conserving the hottest of the hotspots. Biological Conservation, vol. 142, p. 1137. http://dx.doi. org/10.1016/j.biocon.2008.10.011

MATTOZO, VC., FARIA, LRR. and MELO, GAR., 2011. Orchid bees (Hymenoptera: Apidae) in the coastal forests of southern Brazil: diversity, efficiency of sampling methods and comparison with other Atlantic Forest surveys. Papéis Avulsos de Zoologia, vol. 51, p. 505-515.

MELO, AMC., 2005. Gradientes ambientais e a comunidade de abelhas Euglossina (Hymenoptera, Apidae) em fragmentos de Mata Atlântica intercalados por uma matriz de eucaliptais no extremo sul da Bahia. Universidade Federal da Bahia, Salvador, Brazi. 116 p. Unpublished M.Sc. Thesis.

MILET-PINHEIRO, P. and SCHLINDWEIN, C., 2005. Do euglossine males (Apidae, Euglossini) leave tropical rainforest to collect fragrances in sugarcane monocultures? Revista Brasileira de Zoologia, vol. 22, p. 853-858. http://dx.doi.org/10.1590/ S0101-81752005000400008

MITTERMEIER, RA., MYERS, N., GIL, PR. and MITTERMEIER, CG., 1999. Hot spots: Earth's Biologically Richest and Most Endangered Terrestrial Ecoregions. Mexico: CEMEX. 430 p.

MOURE, JS., 1996. [1995] Notas sobre algumas espécies de abelhas da Bahia, Brasil (Hymenoptera, Apoidea). Revista Brasileira de Zoologia, vol. 12, p. 467-470.

MYERS, N., 1988. Threatened biotas: "hot spots" in tropical forests. The Environmentalist, vol. 8, p. 187-208. PMid:12322582. http://dx.doi.org/10.1007/BF02240252

NEMÉSIO, A., 2009. Orchid bees (Hymenoptera: Apidae) of the Brazilian Atlantic Forest. Zootaxa, vol. 2041, p. 1-242.

-, 2010a. Eulaema (Apeulaema) felipei sp. n. (Hymenoptera: Apidae: Euglossina): a new forest-dependent orchid bee found at the brink of extinction in northeastern Brazil. Zootaxa, vol. 2424, p. 51-62.

-, 2010b. The orchid-bee fauna (Hymenoptera: Apidae) of a forest remnant in northeastern Brazil, with new geographic records and an identification key to the known species of the Atlantic Forest of northeastern Brazil. Zootaxa, vol. 2656, p. 55-66.

-, 2011a. The orchid-bee fauna (Hymenoptera: Apidae) of a forest remnant in southern Bahia, Brazil, with new geographic records and an identification key to the known species of the area. Zootaxa, vol. 2821, p. 47-54.

-, 2011b. Euglossa marianae sp. n. (Hymenoptera: Apidae): a new orchid bee from the Brazilian Atlantic Forest and the possible first documented local extinction of a forest dependent orchid bee. Zootaxa, vol. 2892, p. 59-68.

-, 2011c. Exaerete salsai sp. n. (Hymenoptera: Apidae): a new orchid bee from eastern Brazil. Zootaxa, vol. 2967, p. 12-20.

-, 2011d. Euglossa bembei sp. n. (Hymenoptera: Apidae): a new orchid bee from the Brazilian Atlantic Forest belonging to the Euglossa cybelia Moure, 1968 species group. Zootaxa, vol. 3006, p. 43-49.

-, 2011e. Rediscovered after forty-two years: the rare orchid bee Eufriesea brasilianorum (Hymenoptera: Apidae) of eastern Brazil. North-Western Journal of Zoology, vol. 7, p. 356-359.

-, 2012. Species of Euglossa Latreille, 1802 (Hymenoptera: Apidae: Euglossina) belonging to the purpurea species group occurring in eastern Brazil, with description of Euglossa monnei sp. n. Zootaxa, vol. 3151, p. 35-52.

-, 2013. The orchid-bee fauna (Hymenoptera: Apidae) of 'Reserva Biológica de Una', a hotspot in the Atlantic Forest of southern Bahia, eastern Brazil. Brazilian Journal of Biology, vol. 73, n. 2, p. 347-352.

NEMÉSIO, A. and ENGEL, MS., 2012. Three new cryptic species of Eugossa from Brazil (Hymenoptera, Apidae). ZooKeys, vol. 222, p. 47-68. PMid:23129986 PMCid:3459030. http://dx.doi. org/10.3897/zookeys.222.3382

NEMÉSIO, A., CERÂNTOLA, NCM., VASCONCELOS, HL., NABOUT, J.C., SILVEIRA, FA. and DEL LAMA, MA., 2012. Searching for Euglossa cyanochlora Moure, 1996 (Hymenoptera: Apidae), one of the rarest bees in the world. Journal of Insect Conservation, vol. 16, no. 5, p. 745-755. http://dx.doi.org/10.1007/ s10841-012-9459-2

NEMÉSIO, A. and MORATO, EF., 2006. The orchid-bee fauna (Hymenoptera: Apidae) of Acre state (northwestern Brazil) and a re-evaluation of euglossine bait-trapping. Lundiana, vol. 7, p. 59-64.

NEMÉSIO, A. and RASMUSSEN, C., 2011. Taxonomic issues in the orchid bees (Hymenoptera: Apidae: Euglossina), and an updated catalogue. Zootaxa, vol. 3006, p. 1-42.

NEMÉSIO, A. and SILVEIRA, FA., 2006. Edge effects on the orchid-bee fauna (Hymenoptera: Apidae) at a large remnant of Atlantic Forest in southeastern Brazil. Neotropical Entomology, vol. 35, p. 313-323. PMid:18575690. http://dx.doi.org/10.1590/ S1519-566X2006000300004

-, 2007a. Orchid bee fauna (Hymenoptera: Apidae: Euglossina) of Atlantic Forest fragments inside an urban area in southeastern Brazil. Neotropical Entomology, vol. 36, p. 186-191. PMid:17607450. http://dx.doi.org/10.1590/S1519-566X2007000200003

-, 2007b. Diversity and distribution of orchid bees (Hymenoptera: Apidae: Euglossina) with a revised checklist of their species. Neotropical Entomology, vol. 36, p. 874-888. PMid:18246261. http://dx.doi.org/10.1590/S1519-566X2007000600008

-, 2010. Forest fragments with larger core areas better sustain diverse orchid bee faunas (Hymenoptera: Apidae: Euglossina). Neotropical Entomology, vol. 39, p. 555-561. PMid:20877991. http://dx.doi.org/10.1590/S1519-566X2010000400014

NEVES, EL. and VIANA, BF., 2003. A fauna de abelhas da subtribo Euglossina (Hymenoptera: Apidae) do estado da Bahia, Brasil. In MELO, GAR. and ALVES-DOS-SANTOS, I. (Eds.). Apoidea Neotropica: Homenagem aos 90 anos de Jesus Santiago Moure. Criciúma: Universidade do Extremo Sul Catarinense. p. 223-229.

PACHECO, JF., WHITNEY, BM. and GONZAGA, LP., 1996. A new genus and species of furnariid (Aves: Furnariidae) from the cocoa-growing region of southeastern Bahia, Brazil. The Wilson Bulletin, vol. 108, p. 397-433.

PIELOU, EC., 1975. Ecological diversity. New York: John Wiley \& Sons. 165 p. PMid:123462.

REBÊLO, JMM. and GARÓFALO, CA., 1991. Diversidade e sazonalidade de machos de Euglossini (Hymenoptera, Apidae) e preferência por iscas odores em um fragmento de floresta no sudeste do Brasil. Revista Brasileira de Biologia, vol. 51, p. 787-799.

-, 1997. Comunidades de machos de Euglossinae (Hymenoptera, Apidae) em matas semidecíduas do nordeste do estado de São Paulo. Anais da Sociedade Entomológica do Brasil, vol. 26, p. 243-256. http://dx.doi.org/10.1590/S0301-80591997000200005 
RIBEIRO, MC, METZGER, JP., MARTENSEN, AC., PONZONI, FJ. and HIROTA, MM., 2009. The Brazilian Atlantic Forest: how much is left, and how is the remaining forest distributed? Implications for conservation. Biological Conservation, vol. 142, p. 114-1153. http://dx.doi.org/10.1016/j.biocon.2009.02.021

ROUBIK, DW. and HANSON, PE. 2004. Orchid bees of tropical America: biology and field guide. San Jose: INBIO. 370 p.

SAMBUICHI, RHR., OLIVEIRA, RM., MARIANO NETO, E., THÉVENIN, JMR., JESUS JUNIOR, CP., OLIVEIRA, RL. and PELIÇÃO, LC., 2008. Status de conservação de dez árvores endêmicas da Floresta Atlântica do sul da Bahia - Brasil. Natureza \& Conservação, vol. 6, p. 90-108.

SANTOS, AM. and SOFIA, SH., 2002. Horário de atividade de machos de Euglossinae (Hymenoptera, Apidae) em um fragmento de floresta semidecídua no norte do estado do Paraná. Acta Scientiarum, vol. 24, p. 375-381.

SILVEIRA, GC., NASCIMENTO, AM., SOFIA, SH. and AUGUSTO, SC., 2011. Diversity of the euglossine bee community (Hymenoptera, Apidae) of an Atlantic Forest remnant in southeastern Brazil. Revista Brasileira de Entomologia, vol. 55, p. 109-115. http://dx.doi.org/10.1590/S0085-56262011000100017

SNEATH, PHA. and SOKAL, RR., 1973. Numerical taxonomy: The principles and practice of numerical classification, San Francisco: W. H. Freeman. 573 p.
THOMAS, WW. and CARVALHO, AM., 2003. Zoneamento Ecológico do Sudeste da Bahia, Brasil (mapa em formato digital). In PRADO, PI., LANDAU, EC., MOURA, RT., PINTO, LPS., FONSECA, GAB. and ALGER, K. (Orgs.). Corredor de Biodiversidade da Mata Atlântica do Sul da Bahia. Ilhéus: IESB/ Conservation International. Published in CD-ROM.

THOMAS, WW., CARVALHO, AM., and HERRERA-MacBRYDE, O., 1997. Atlantic moist forest of southern Bahia: South-eastern Brazil. In World Wide Fund - WWF and International Union for Conservation of Nature - IUCN. Centers of plant diversity: A guide and strategy for their conservation. Cambridge: IUCN Publications Unit. v. 3, p. 364-368.

THOMAS, WW., CARVALHO, AM., AMORIM, AMA., GARRISON, J., and ABERLÁEZ, AL., 1998. Plant endemism in two forests in southern Bahia. Biodiversity and Conservation, vol. 7, p. 311-322. http://dx.doi.org/10.1023/A:1008825627656

TONHASCA JUNIOR, A., BLACKMER, JL. and ALBUQUERQUE, GS., 2002. Abundance and diversity of euglossine bees in the fragmented landscape of the Brazilian Atlantic Forest. Biotropica, vol. 34, p. 416-422.

WOLDA, H., 1981. Similarity indices, sample sizes and diversity. Oecologia, vol. 50, p. 296-302. http://dx.doi.org/10.1007/ BF00344966 